\title{
Backbone-Constrained Peptides: Temperature and Secondary Structure Affect Solid-State Electron Transport
}

Cunlan Guo, ${ }^{\dagger, \S, *}$ Jingxian Yu, ${ }^{\ddagger} *$ John R. Horsley, ${ }^{\ddagger}$ Mordechai Sheves, ${ }^{\dagger}$ David Cahen, ${ }^{\dagger}$ and Andrew D. Abell ${ }^{\ddagger}$

${ }^{\dagger}$ Department of Materials and Interfaces, Weizmann Institute of Science, Rehovot, 76100, Israel

${ }^{\ddagger}$ ARC Centre of Excellence for Nanoscale BioPhotonics (CNBP), Institute of Photonics and Advanced Sensing (IPAS), Department of Chemistry, The University of Adelaide, Adelaide, SA 5005, Australia

$\S$ Present address: College of Chemistry and Molecular Sciences, Wuhan University, No. 299 Bayi Road, Wuhan, Hubei 430072, P.R China

Email: cunlanguo@whu.edu.cn; Jingxian.yu@adelaide.edu.au

Phone: +86-2768754085; +61-8-83136694

\section{Table of Contents:}

1. Peptide synthesis

Page S2

2. NMR and MS data for peptides 1-4

Page S8

3. Computational conformational data for peptides 1-4

Page S10

4. PM-IRRAS, AFM, and ellipsometry data for peptides 1-4

Page S14

5. Temperature-dependent conductance measurements for peptides 1-4

Page S16

6. Temperature-dependent $\alpha$-helical content of self-assembled peptides 1-4 Page S17

7. Analysis of MD data for mobility (RMSF) per residue

Page S18 


\section{Peptide Synthesis}

\section{Scheme S1 Synthesis of alkene sidechain}
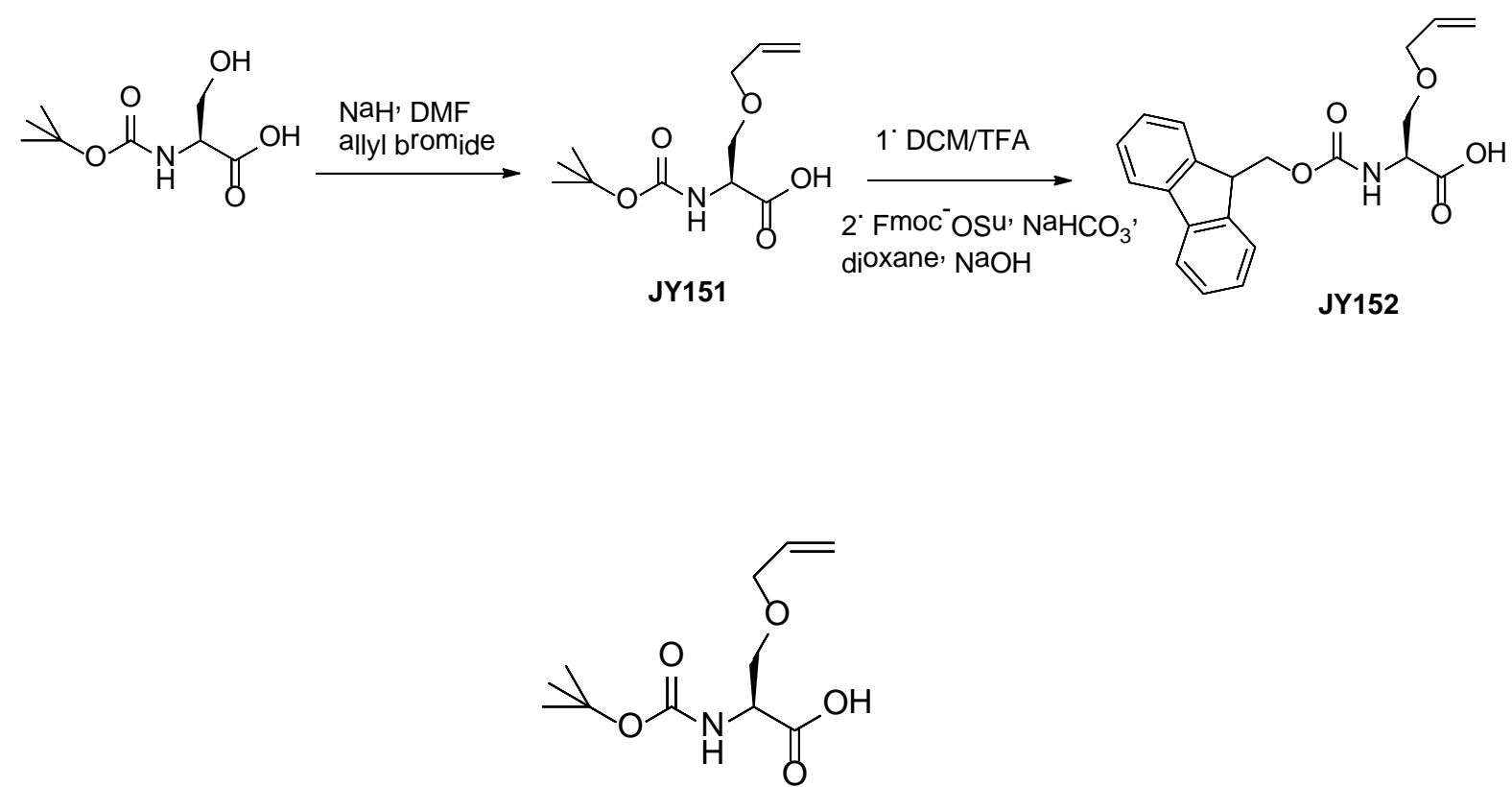

\section{JY151}

Boc-Ser-OH (10.48 g, $51.12 \mathrm{mmol}$ ) was dissolved in anhydrous DMF (30 mL) and stirred under $\mathrm{N}_{2}$ at r.t. $\mathrm{NaH}$ (60\% dispersion in mineral oil (5.08 g)) was suspended in anhydrous DMF $(90 \mathrm{~mL})$ and stirred under $\mathrm{N}_{2}$ over an ice bath $\left(0{ }^{\circ} \mathrm{C}\right)$. The Boc-Ser$\mathrm{OH}$ solution was added to the $\mathrm{NaH}$ suspension dropwise and the reaction stirred for $30 \mathrm{~min}$. The ice bath was removed and allyl bromide $(4 \mathrm{~mL})$ added, and the reaction stirred for a further $3 \mathrm{~h}$. The reaction was then quenched with $\mathrm{H}_{2} \mathrm{O}(30 \mathrm{~mL}$ ) and the solvent removed with $\mathrm{N}_{2}$. The crude residue was dissolved in $\mathrm{H}_{2} \mathrm{O}(200 \mathrm{~mL})$ and EtOAc (200 mL) and the $\mathrm{pH}$ adjusted to $\mathrm{pH}$ 2. The organic layer was collected, washed with $\mathrm{H}_{2} \mathrm{O}$ and brine, and dried over $\mathrm{MgSO}_{4}$. The solvent was removed in vacuo to reveal yellow/brown oil (10.5 g). The crude sample was purified using flash chromatography (eluent EtOAc/petroleum ether: 40\% / 60\%) to yield pale yellow oil (9.77 g, 78\%). 


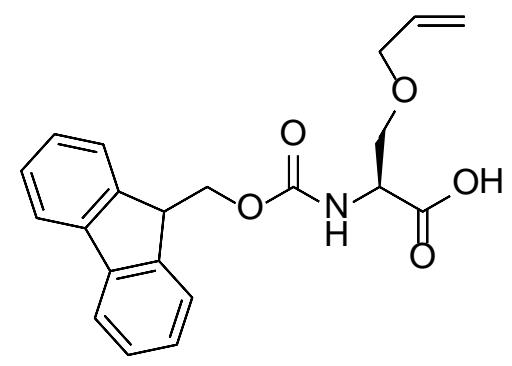

JY152

JY151 (9.77 g, $39.87 \mathrm{mmol})$ was dissolved in DCM (20 mL) and stirred over an ice bath $\left(0{ }^{\circ} \mathrm{C}\right)$. TFA $(20 \mathrm{~mL})$ was added dropwise and stirred for $30 \mathrm{~min}$. The ice bath was removed and reaction stirred for a further $30 \mathrm{~min}$. The solvent was removed in vacuo to reveal a white TFA salt $(10.15 \mathrm{~g}, 39.20 \mathrm{mmol})$. The Boc-deprotected compound was then dissolved in 1-4 dioxane (55 mL) and one equivalent $\mathrm{NaOH}$ (1.56 g, in $\mathrm{H}_{2} \mathrm{O}(15 \mathrm{~mL})$ ) added to neutralize the TFA. $\mathrm{NaHCO}_{3}$ (2 equiv.) and Fmoc-OSu ( 1 equiv.) were added and the reaction stirred for $12 \mathrm{~h}$. The solvent was removed in vacuo and the residue redissolved in $\mathrm{NaHCO}_{3}(200 \mathrm{~mL}, 2.5 \% \mathrm{w} / \mathrm{v})$, washed with diethyl ether (x3), and acidified to pH2. EtOAc (4 x $200 \mathrm{~mL})$ extractions were performed and the combined organic layers washed with brine and dried over $\mathrm{MgSO}_{4}$. The solvent was removed in vacuo to reveal a white solid (12.45 g, 82\%). Reverse phase HPLC revealed one peak representative of pure product.

\section{Solid Phase Peptide Synthesis (SPPS)}

Peptides 3 and 4 were synthesized using SPPS. Standard Fmoc-based SPPS and commercially available reagents were used for the synthesis of both peptides. 2Chlorotrityl resin preloaded with Fmoc-Aib-OH (0.80 mmol g ${ }^{-1}, 1.0$ g, 1 equiv.) was used for both linear peptides. The unreacted active sites on the resin were capped with DCM/MeOH/DIPEA (17:2:1, 2x25 mL) for 30 min and the resin washed with DCM (x3), DMF (x3) and DCM (x3). $N$-Fmoc deprotection was conducted by treating the resin with $25 \%$ piperidine/DMF (25 mL) for 30 min before washing with DCM (x3), DMF (x3) and DCM (x3). Each sequential amino acid was coupled using the following molar ratios of reagents: Fmoc-amino acids were each dissolved in DMF 
(20 mL), 1-[bis(dimethylamino)methylene]-1H-1,2,3-triazolo[4,5-b]pyridinium 3oxid hexafluorophosphate (HATU)/DMF (0.5 M, 2 equiv.) and DIPEA (4 equiv.). The resin was then washed with DCM (x3) and DMF (x3) followed by DCM (x3), and the coupling procedures repeated. The coupling time was a minimum of $2 \mathrm{~h}$ in all cases. Following coupling with the final residue for each linear peptide (3(tritylthio)propionic acid), the resins were washed with DCM (x3), DMF (x3) and DCM (x3) and dried under vacuum. Treatment with 95\% TFA/2.5\% TIPS/2.5\% $\mathrm{H}_{2} \mathrm{O}$ (15 $\mathrm{mL}$ ) for $10 \mathrm{~min}$ resulted in cleavage from the resin as well as deprotection of the trityl group from the $\mathrm{N}$-terminal. The filtrate containing each peptide was collected and the TFA removed using $\mathrm{N}_{2}$. Each peptide was placed under vacuum before being purified using reverse phase HPLC. 


\section{Scheme S2 Synthesis of peptide 1}

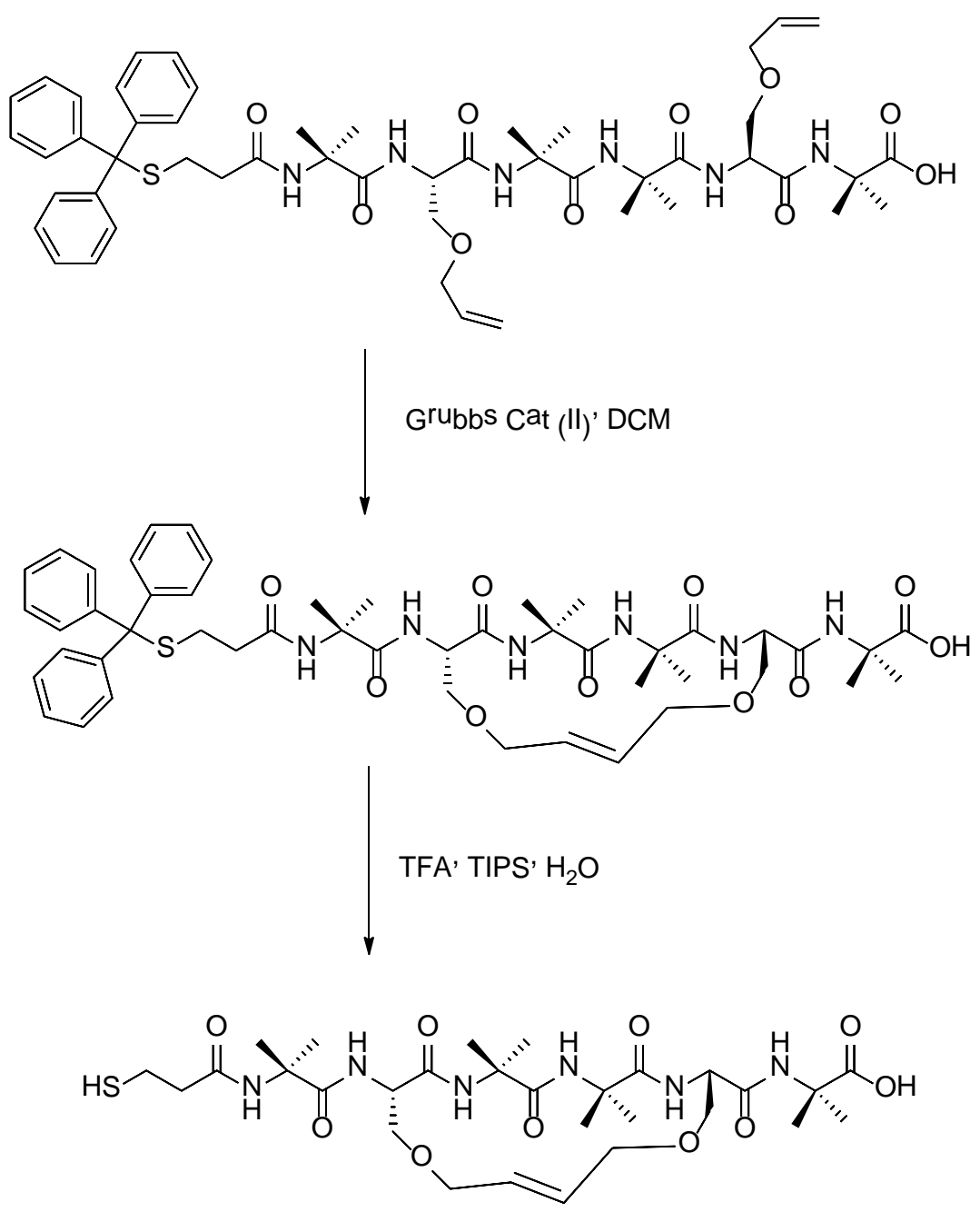

The unsaturated cyclic peptide $\mathbf{1}$ was prepared from the linear peptide comprising two alkene-containing sidechains described above, using Ring Closing Metathesis (RCM). The linear peptide in this case was cleaved from the resin using 1.5\% TFA, so as to retain the trityl protecting group, as shown in Scheme S2 (top). The trityl-protected linear peptide was then purified using column chromatography with EtOAc/petroleum ether (90\% / 10\%) as the eluent. The purified compound (280 mg, $0.298 \mathrm{mmol}$ ) was dissolved in anhydrous DCM (30 mL) and stirred under reflux for a total of $3.5 \mathrm{~h}$ at $50{ }^{\circ} \mathrm{C}$ under $\mathrm{N}_{2}$ atmosphere. A total of $4.5 \%$ molar equiv. of Grubbs Cat (II) was used (11 mg, $0.013 \mathrm{mmol}$ ), which was divided into three batches of 1.5\% molar equiv. (3x $3.7 \mathrm{mg})$. The first batch was dissolved in anhydrous DCM (500 $\mu \mathrm{L})$ and added as soon as the peptide solution had reached $50{ }^{\circ} \mathrm{C}$. After $1 \mathrm{~h}$, the next batch was added, 
with the final batch added after $2 \mathrm{~h}$. The reaction solution was stirred under $\mathrm{N}_{2}$ for a further $1.5 \mathrm{~h}$, and allowed to cool to rt. Activated charcoal (110 mg) was added and the reaction stirred for $72 \mathrm{~h}$. The mixture was then vacuum filtered through celite and the filtrate washed with DCM (x3) and $\mathrm{MeOH}$ (x3). The solvent was removed in vacuo to reveal crude brown oil (270 mg), which was purified using column chromatography (DCM/MeOH (95\% / 5\%)). The trityl group was removed using 95\% TFA/2.5\% TIPS/2.5\% $\mathrm{H}_{2} \mathrm{O}(15 \mathrm{~mL})$ for $1 \mathrm{~h}$. The crude residue was purified using reverse phase HPLC to reveal a white solid, which was used for conductance measurements. 


\section{Scheme S3 Synthesis of peptide 2}

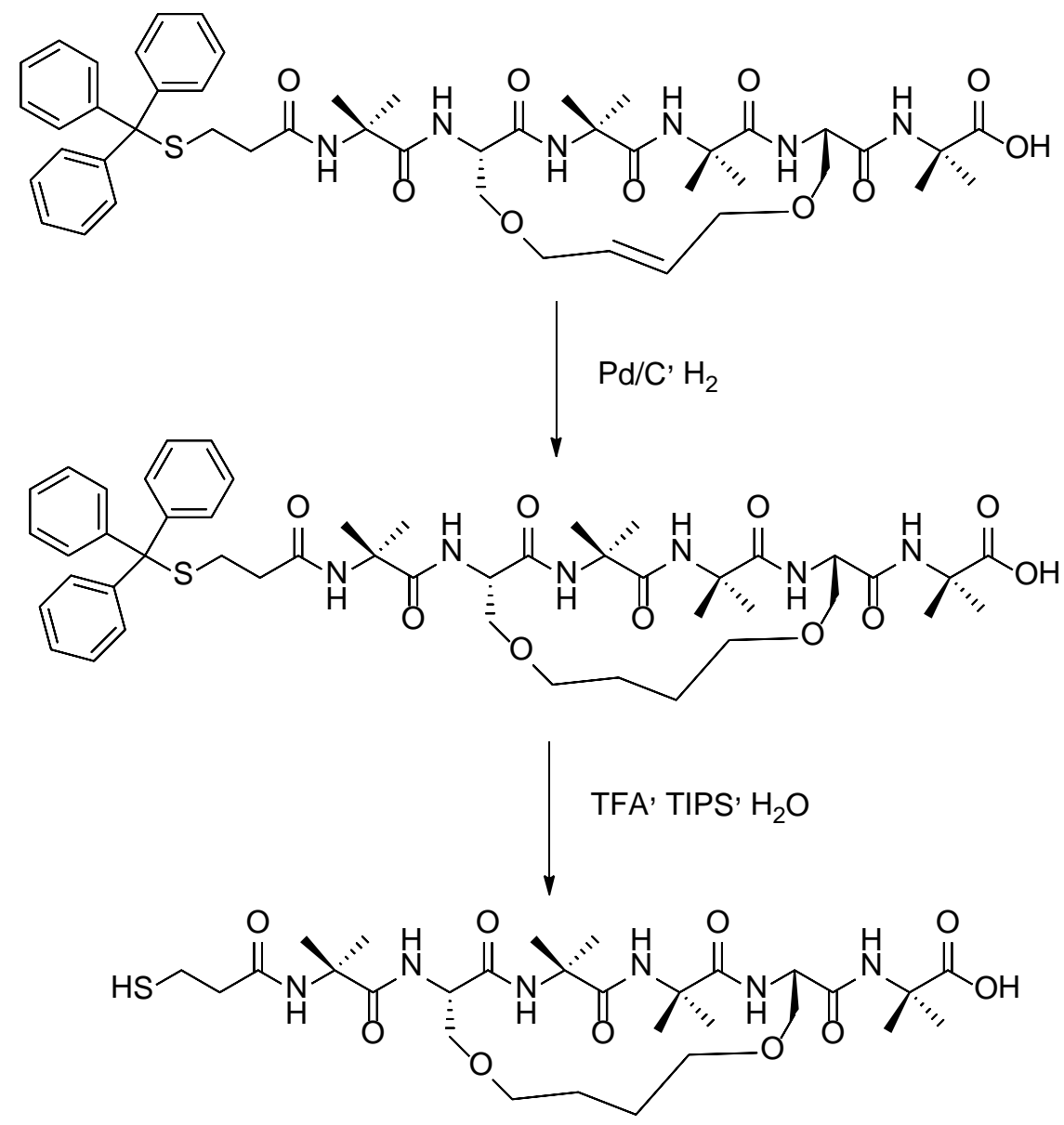

The purified trityl-protected unsaturated peptide (Scheme S3, top) was dissolved in EtOAc and $\mathrm{Pd} / \mathrm{C}(10 \% \mathrm{w} / \mathrm{w})$ was added. The reaction mixture was stirred and exposed to $\mathrm{H}_{2}$ gas for $16 \mathrm{~h}$. The solvent was filtered through celite and the filtrate washed with DCM (x3) and $\mathrm{MeOH}(\mathrm{x} 3)$ to reveal crude product, which was treated with 95\% TFA/2.5\% TIPS/2.5\% $\mathrm{H}_{2} \mathrm{O}$ (3 mL) for $1 \mathrm{~h}$ to remove the trityl group. The TFA was removed by $\mathrm{N}_{2}$, and the crude product purified using reverse phase HPLC and used for conductance measurements. 


\section{NMR and MS data for peptides 1-4}

Peptide $1{ }^{1} \mathrm{H}$ NMR (600 MHz, DMSO-d6) $\delta 8.30$ (s, 1H, NH Aib1), $\delta 8.10$ (s, 1H, NH Aib2), $\delta 7.94$ (m, 1H, NH sidechain1), $\delta 7.72$ (s, 1H, NH Aib3), $\delta 7.51$ (m, 1H, NH sidechain2), $\delta 7.44$ (s, $1 \mathrm{H}, \mathrm{NH}$ Aib4), $\delta$ 5.63- $\delta 5.61\left(\mathrm{~m}, 2 \mathrm{H}, \mathrm{OCH}_{2} \mathrm{CHCH}\right), \delta$

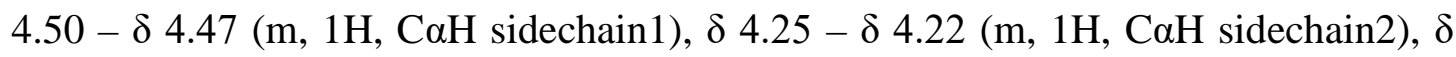
4.12 (d, 1H, OCHHCH, $J=13.3 \mathrm{~Hz}$ ), $\delta 4.01-\delta 3.94$ (m, 3H, $\mathrm{C} \alpha \mathrm{HCH}_{2} \mathrm{O}$ sidechain1, $\mathrm{C} \alpha H C H_{2} \mathrm{OCHH}$ sidechain2), $\delta 3.88-\delta 3.85$ (m, 1H, $\mathrm{C} \mathrm{HCH}_{2} \mathrm{OCH} H$ sidechain2), $\delta$ $3.75-\delta 3.72(\mathrm{~m}, 1 \mathrm{H}, \mathrm{OCH} H \mathrm{CH}), \delta 3.66-\delta 3.57$ (m, 4H, $\mathrm{C} \alpha \mathrm{HCH}_{2} \mathrm{O}$ sidechain2, $\mathrm{CH}_{2} \mathrm{CH}_{2} \mathrm{SH}$ ), $\delta 3.13-\delta 3.09$ (m, 2H, $\mathrm{CH}_{2} \mathrm{CH}_{2} \mathrm{SH}$ ), $\delta 1.35-\delta 1.29$ (m, 24H, 8xCH ); ${ }^{13} \mathrm{C}$ NMR (600 MHz, DMSO-d6) $\delta$ 175.04, 174.72, 174.46. 174.00, 171.13, 168.24, 129.62, 128.40, 56.35, 56.15, 55.82, 54.86, 53.52, 28.81, 28.69, 28.56, 27.30, 26.59, 25.57, 24.91, 24.64, 24.51, 23.30, 22.76, 22.08, 19.73, 18.05, 16.72, 12.44.

HRMS $[\mathrm{M}+\mathrm{H}]^{+}$calc'd $=673.3231,[\mathrm{M}+\mathrm{H}]^{+}$found $=673.3252$.

Peptide $2{ }^{1} \mathrm{H}$ NMR (600 MHz, DMSO-d6) $\delta 8.27$ (s, 1H, NH Aib), $\delta 8.04$ (s, 1H, NH Aib), $\delta 7.92$ (d, 1H, NH, $J=7.2$ Hz), $\delta 7.55$ (s, 1H, NH Aib), $\delta 7.47$ (m, 1H, NH Aib), $\delta 7.43$ (d, 1H, NH, $J=6.4 \mathrm{~Hz}$ ), $\delta 4.59-\delta 4.56(\mathrm{~m}, 1 \mathrm{H}, \mathrm{C} \alpha \mathrm{H}), \delta 4.36-\delta 4.32$ (m, 1H, C $\alpha \mathrm{H}), \delta 4.03-\delta 4.00(\mathrm{~m}, 1 \mathrm{H}, \mathrm{C} \alpha \mathrm{HCHHO}), \delta 3.89-\delta 3.86(\mathrm{~m}, 1 \mathrm{H}$ $\mathrm{C} \alpha \mathrm{HCHHO}$ ), $\delta 3.64-\delta 3.55\left(\mathrm{~m}, 4 \mathrm{H}, \mathrm{C} \alpha H C H_{2} \mathrm{O}, \mathrm{CH}_{2} \mathrm{CH}_{2} \mathrm{SH}\right), \delta 3.15-\delta 3.12(\mathrm{~m}$, $\left.2 \mathrm{H}, \mathrm{CH}_{2} \mathrm{CH}_{2} \mathrm{SH}\right), \delta 2.19-\delta 2.17\left(\mathrm{~m}, 2 \mathrm{H}, \mathrm{OCH}_{2} \mathrm{CH}_{2}\right), \delta 2.02-\delta 1.99(\mathrm{~m}, 2 \mathrm{H}$, $\left.\mathrm{OCH}_{2} \mathrm{CH}_{2}\right), \delta 1.48-1.44\left(\mathrm{~m}, 4 \mathrm{H}, 2 \mathrm{xOCH}_{2} \mathrm{CH}_{2}\right), \delta 1.34-\delta 1.27$ (m, 24H, 8xCH$)_{3}$. HRMS $[\mathrm{M}+\mathrm{H}]^{+}$calc'd $=675.3387,[\mathrm{M}+\mathrm{H}]^{+}$found $=675.6076$.

Peptide $3{ }^{1} \mathrm{H}$ NMR (500 MHz, DMSO-d6) $\delta 8.43$ (s, 1H, NH Aib1), $\delta 8.00$ (s, 1H, NH Aib2), $\delta 7.89$ (d, 1H, NH sidechain1, $J=5.9$ Hz), $\delta 7.44$ (s, 1H, NH Aib4), $\delta 7.42$ (m, 1H, NH Aib3), $\delta 7.39(\mathrm{~m}, 1 \mathrm{H}, \mathrm{NH}$ alanine), $\delta 5.88-\delta 5.81(\mathrm{~m}, 1 \mathrm{H}$, $\left.\mathrm{OCH}_{2} \mathrm{CHCH}_{2}\right), \delta 5.23\left(\mathrm{~d}, 1 \mathrm{H}, \mathrm{OCH}_{2} \mathrm{CHCHH}, J=17.3 \mathrm{~Hz}\right), \delta 5.13(\mathrm{~d}, 1 \mathrm{H}$, $\mathrm{OCH}_{2} \mathrm{CHCH} H, J=10.4 \mathrm{~Hz}$ ), ), $\delta 4.16-\delta 4.12(\mathrm{~m}, 1 \mathrm{H}, \mathrm{C} \alpha \mathrm{H}$ sidechain), $\delta 4.05-\delta$ 4.00 (m, 1H, CaH alanine), $\delta 3.97-\delta 3.92$ (m, 2H, $\left.\mathrm{OCH}_{2} \mathrm{CHCH}_{2}\right), \delta 3.71-\delta 3.64$ 
(m, $\left.2 \mathrm{H}, \mathrm{C} \alpha \mathrm{HCH}_{2} \mathrm{O}\right), \delta 2.75-\delta 2.65\left(\mathrm{~m}, 2 \mathrm{H}, \mathrm{CH}_{2} \mathrm{CH}_{2} \mathrm{SH}\right), \delta 2.49-\delta 2.44(\mathrm{~m}, 1 \mathrm{H}$, $\left.\mathrm{CHHCH}_{2} \mathrm{SH}\right), \delta 2.32-\delta 2.29\left(\mathrm{~m}, 1 \mathrm{H}, \mathrm{CHHCH}_{2} \mathrm{SH}\right), \delta 1.75-\delta 1.70(\mathrm{~m}, 1 \mathrm{H}, \mathrm{SH}), \delta$ $1.37-\delta 1.31(\mathrm{~m}, 24 \mathrm{H}, 8 \mathrm{xCH}), \delta 1.25\left(\mathrm{~m}, 3 \mathrm{H}, \mathrm{CH}_{3}\right.$, alanine).

HRMS $[\mathrm{M}+\mathrm{H}]^{+}$calc'd $=645.3282,[\mathrm{M}+\mathrm{H}]^{+}$found $=645.3222$.

Peptide $4{ }^{1} \mathrm{H}$ NMR (600 MHz, DMSO-d6) $\delta 8.47$ (s, 1H, NH Aib1), $\delta 8.04$ (s, 1H, NH Aib2), $\delta 7.93$ (d, 1H, NH sidechain1, $J=5.6$ Hz), $\delta 7.50$ (s, 1H, NH Aib4), $\delta 7.48$ (s, 1H, NH Aib3), $\delta 7.42(\mathrm{~m}, 1 \mathrm{H}, \mathrm{NH}$ sidechain2), $\delta 5.86-\delta 5.82(\mathrm{~m}, 2 \mathrm{H}$, $\left.2 \mathrm{xOCH}_{2} \mathrm{CHCH}_{2}\right), \delta 5.25-\delta 5.09\left(\mathrm{~m}, 4 \mathrm{H}, 2 \mathrm{xOCH}_{2} \mathrm{CHCH}_{2}\right), \delta 4.23-\delta 4.20(\mathrm{~m}, 1 \mathrm{H}$, $\mathrm{C} \alpha \mathrm{H}$ sidechain2), $\delta 4.13-\delta 4.10$ (m, 1H, CaH sidechain1), $\delta 3.95-\delta 3.93(\mathrm{~m}, 4 \mathrm{H}$, $\left.2 \mathrm{xOCH}_{2} \mathrm{CHCH}_{2}\right), \delta 3.71-\delta 3.64\left(\mathrm{~m}, 4 \mathrm{H}, 2 \mathrm{x} \mathrm{C \alpha HCH} \mathrm{C}_{2} \mathrm{O}\right), \delta 2.69-\delta 2.65(\mathrm{~m}, 2 \mathrm{H}$, $\left.\mathrm{CH}_{2} \mathrm{CH}_{2} \mathrm{SH}\right), \delta 2.51-\delta 2.47\left(\mathrm{~m}, 1 \mathrm{H}, \mathrm{CHHCH} \mathrm{SH}_{2}, \delta 2.32-\delta 2.29(\mathrm{~m}, 1 \mathrm{H}\right.$, $\left.\mathrm{CHHCH}_{2} \mathrm{SH}\right), \delta 1.36-\delta 1.33\left(\mathrm{~m}, 24 \mathrm{H}, 8 \mathrm{xCH}_{3}\right) ;{ }^{13} \mathrm{C}$ NMR (600 MHz, DMSO-d6) $\delta$ 175.08, 174.72, 173.92, 171.38, 170.65, 135.13, 134.83, 116.28, 116.10, 70.96, 70.84, 69.19, 68.05, 56.19, 56.04, 55.79, 54.78, 27.68, 26.53, 25.61, 24.74, 24.68, 24.23, 23.85, 23.33, 19.78.

HRMS $[\mathrm{M}+\mathrm{H}]^{+}$calc'd $=701.3544,[\mathrm{M}+\mathrm{H}]^{+}$found $=701.3513$.

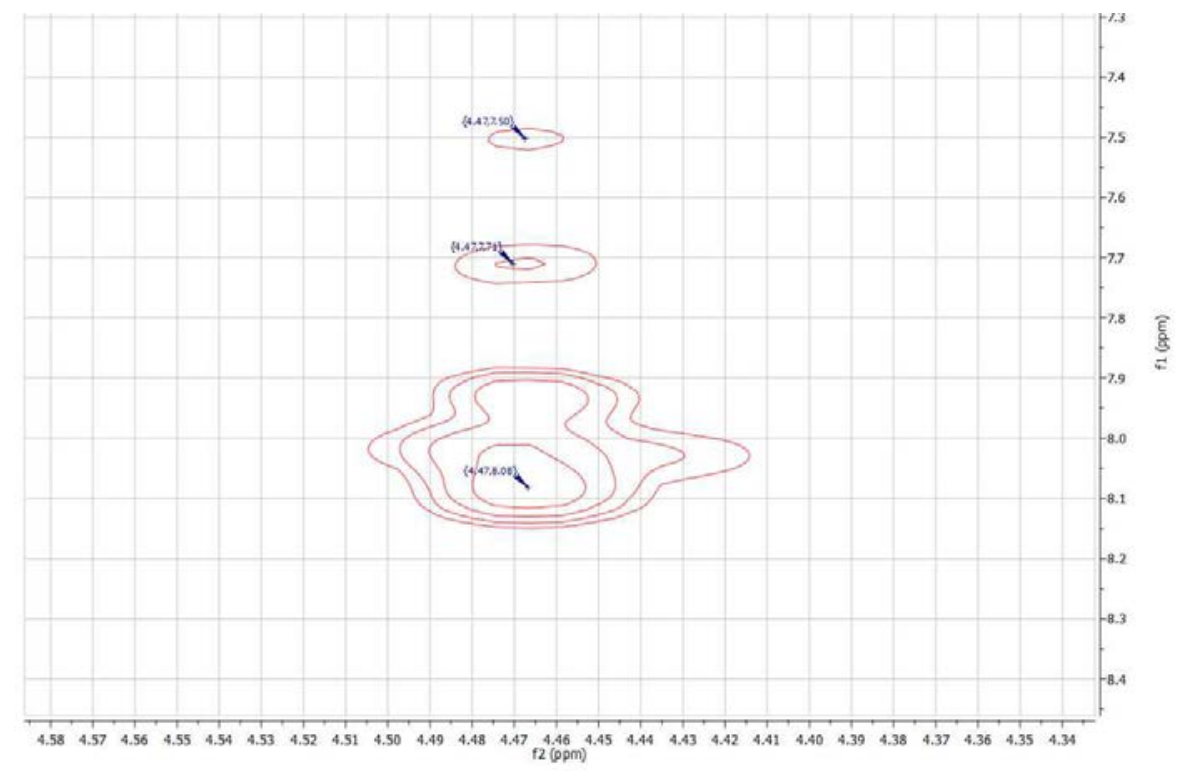

Figure S1. $\mathrm{C} \alpha \mathrm{H}$ (i) to $\mathrm{NH}(i+3)$ ROESY correlations for peptide 1 indicating the presence of a 310 -helical structure. 


\section{Computational conformational data for peptides 1-4}

Table S1. Dihedral angles for all residues in the lowest energy conformers for peptides 1-4.

\begin{tabular}{|c|c|c|c|c|c|c|c|c|}
\hline & \multicolumn{2}{|c|}{ peptide 1 } & \multicolumn{2}{c|}{ peptide 2 } & \multicolumn{2}{c|}{ peptide 3 } & \multicolumn{2}{c|}{ peptide 4 } \\
\cline { 2 - 9 } & $\Phi$ & $\psi$ & $\Phi$ & $\psi$ & $\Phi$ & $\psi$ & $\Phi$ & $\psi$ \\
\hline Residue 1 & -60.336 & -30.192 & -60.428 & -29.753 & -59.959 & -29.975 & -59.892 & -30.597 \\
\hline Residue 2 & -62.312 & -17.854 & -62.267 & -18.848 & -52.231 & -32.138 & -55.717 & -25.606 \\
\hline Residue 3 & -51.101 & -30.099 & -53.249 & 25.954 & -54.688 & -29.164 & -52.411 & -35.026 \\
\hline Residue 4 & -53.296 & -30.137 & -52.338 & -29.089 & -54.901 & 26.944 & -57.618 & -22.224 \\
\hline Residue 5 & -69.220 & -10.255 & -63.394 & -17.485 & -56.596 & -27.593 & -60.109 & -22.784 \\
\hline Residue 6 & -61.497 & -25.525 & -61.452 & -24.811 & -61.920 & -24.008 & -62.109 & -24.490 \\
\hline
\end{tabular}

Table S2. Distances critical to the characterization of a $33_{10}$-helical peptide.

\begin{tabular}{|c|c|c|c|c|c|}
\hline & $\begin{array}{l}\text { Ideal } 3_{10^{-}} \\
\text {helical } \\
\text { distances } \\
\text { (Å) }\end{array}$ & $\begin{array}{c}\text { peptide } 1 \\
\text { (Å) }\end{array}$ & $\begin{array}{c}\text { peptide } 2 \\
\text { (Å) }\end{array}$ & $\begin{array}{c}\text { peptide } 3 \\
\text { (Å) }\end{array}$ & $\begin{array}{c}\text { peptide } 4 \\
(\AA)\end{array}$ \\
\hline $\begin{array}{l}\mathrm{C} \alpha \mathrm{H}(i) \text { to } \\
\mathrm{NH}(i+1)\end{array}$ & 3.4 & 3.4 & 3.4 & 2.9 & 3.0 \\
\hline $\begin{array}{l}\mathrm{C} \beta \mathrm{H}_{2}(i) \text { to } \\
\mathrm{NH}(i+1)\end{array}$ & $2.9-4.4$ & $3.3-4.2$ & $3.2-4.1$ & $4.2-4.6$ & $4.2-4.5$ \\
\hline
\end{tabular}

Table S3. Intramolecular hydrogen bond lengths in $(\AA)$.

\begin{tabular}{ccccc}
\hline Residue & peptide $\mathbf{1}$ & peptide 2 & peptide 3 & peptide 4 \\
\hline 1 & 2.054 & 2.073 & 2.081 & 2.055 \\
2 & 2.240 & 2.223 & 2.171 & 2.187 \\
3 & 2.008 & 2.059 & 2.034 & 1.911 \\
4 & 2.111 & 2.084 & 2.175 & 2.237 \\
5 & 2.160 & 2.108 & 2.080 & 2.114 \\
\hline Average & $\mathbf{2 . 1 1 4}$ & $\mathbf{2 . 1 0 9}$ & $\mathbf{2 . 1 0 8}$ & $\mathbf{2 . 1 0 0}$ \\
\hline
\end{tabular}




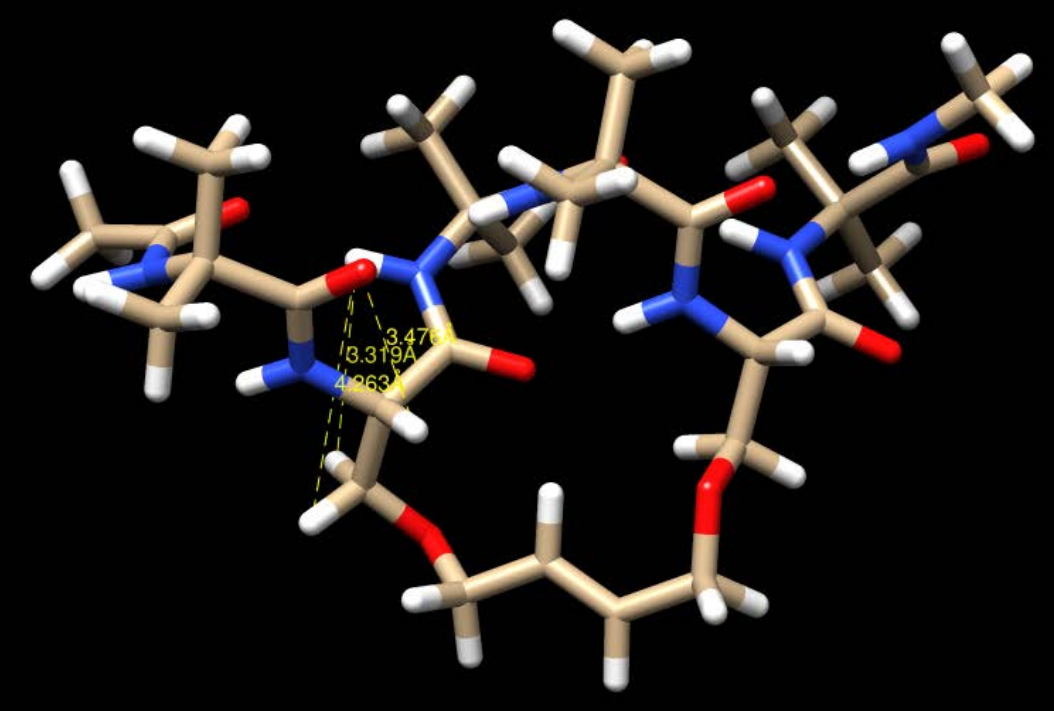

Figure S2. Lowest energy conformer of peptide 1 showing distances for $\mathrm{C} \alpha \mathrm{H}$ (i) to $\mathrm{NH}(i+1)$ and $\mathrm{C}_{3} \mathrm{H}_{2}(i)$ to $\mathrm{NH}(i+1)$ interactions.

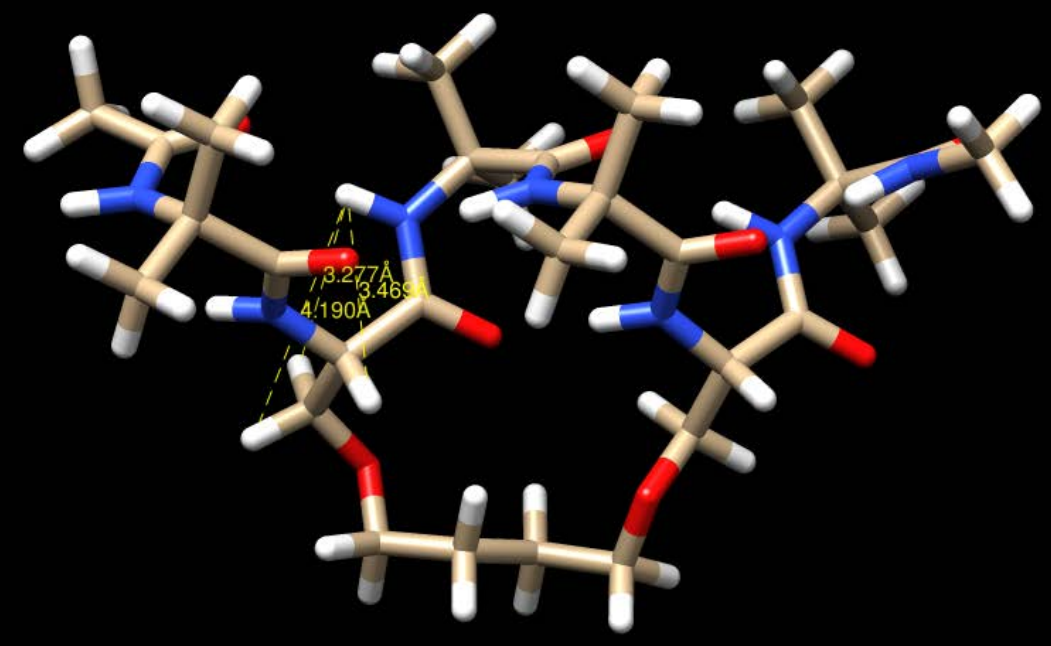

Figure S3. Lowest energy conformer of peptide 2 showing distances for $\mathrm{C} \alpha \mathrm{H}$ (i) to $\mathrm{NH}(i+1)$ and $\mathrm{C} \mathrm{H}_{2}(i)$ to $\mathrm{NH}(i+1)$ interactions. 


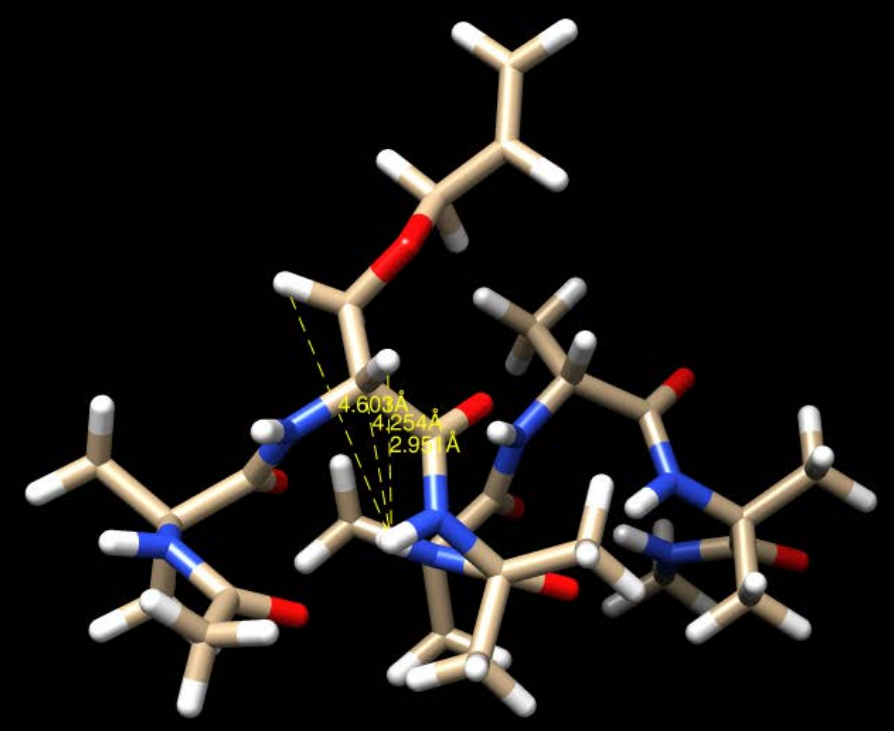

Figure S4. Lowest energy conformer of peptide 3 showing distances for $\mathrm{C} \alpha \mathrm{H}$ (i) to $\mathrm{NH}(i+1)$ and $\mathrm{C} \mathrm{H}_{2}(i)$ to $\mathrm{NH}(i+1)$ interactions.

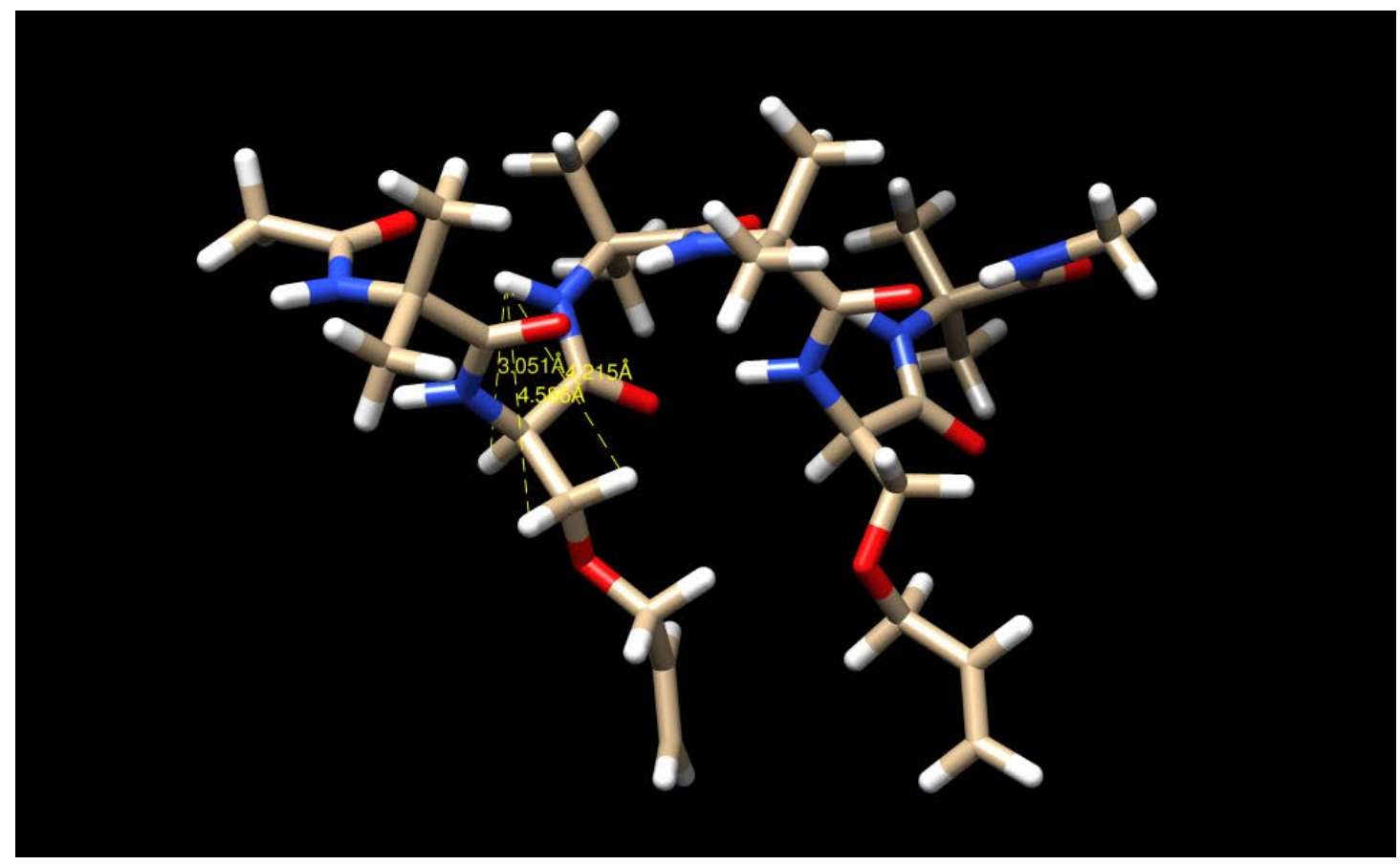

Figure S5. Lowest energy conformer of peptide 4 showing distances for $\mathrm{C} \alpha \mathrm{H}$ (i) to $\mathrm{NH}(i+1)$ and $\mathrm{C} \mathrm{H}_{2}(i)$ to $\mathrm{NH}(i+1)$ interactions. 


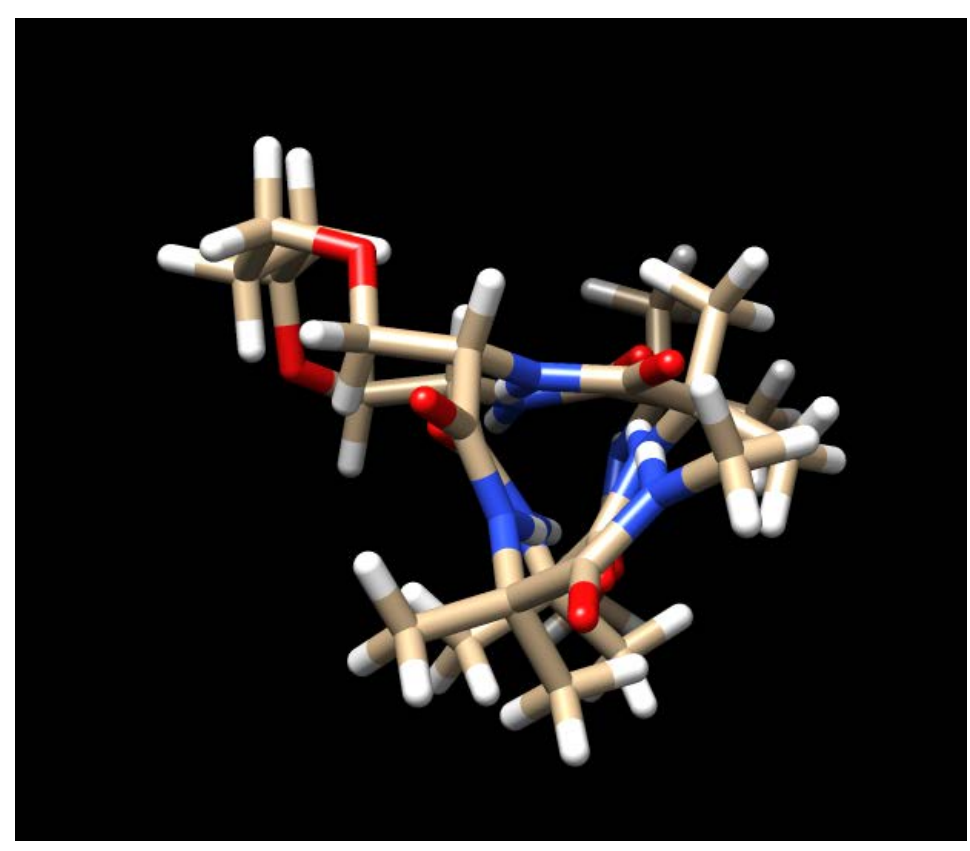

Figure S6. Top view looking down helix showing a triangular-shaped void in the center characteristic of a 310 -helix in peptide 2 . 


\section{PM-IRRAS, AFM, and ellipsometry data for peptides 1-4}

Table S4. Overview of Amide I and Amide II IR absorption peaks for peptide monolayers.

\begin{tabular}{cccc}
\hline & Amide I $\left(\mathrm{cm}^{-1}\right)$ & Amide II $\left(\mathrm{cm}^{-1}\right)$ & Amide I/II \\
\hline peptide 1 & 1668 & 1537 & 3.1 \\
peptide 2 & 1669 & 1538 & 3.1 \\
peptide 3 & 1669 & 1540 & 4.08 \\
peptide 4 & 1669 & 1540 & 3.21 \\
\hline
\end{tabular}

(a)

(c)
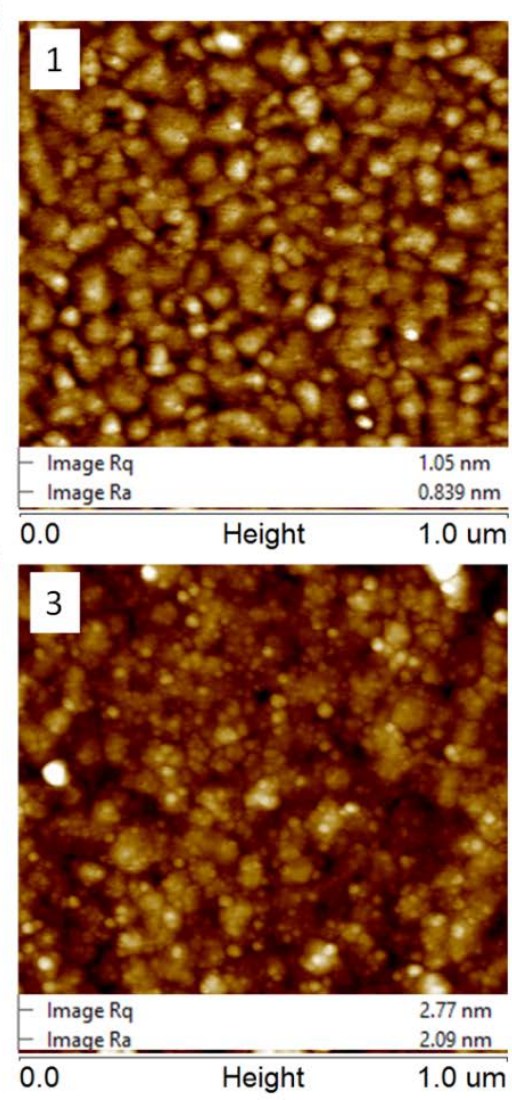

(b)

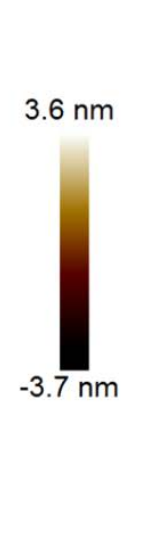

(d)

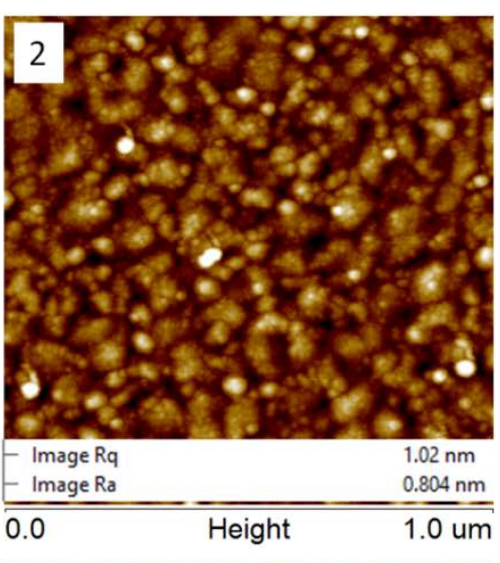

$3.7 \mathrm{~nm}$
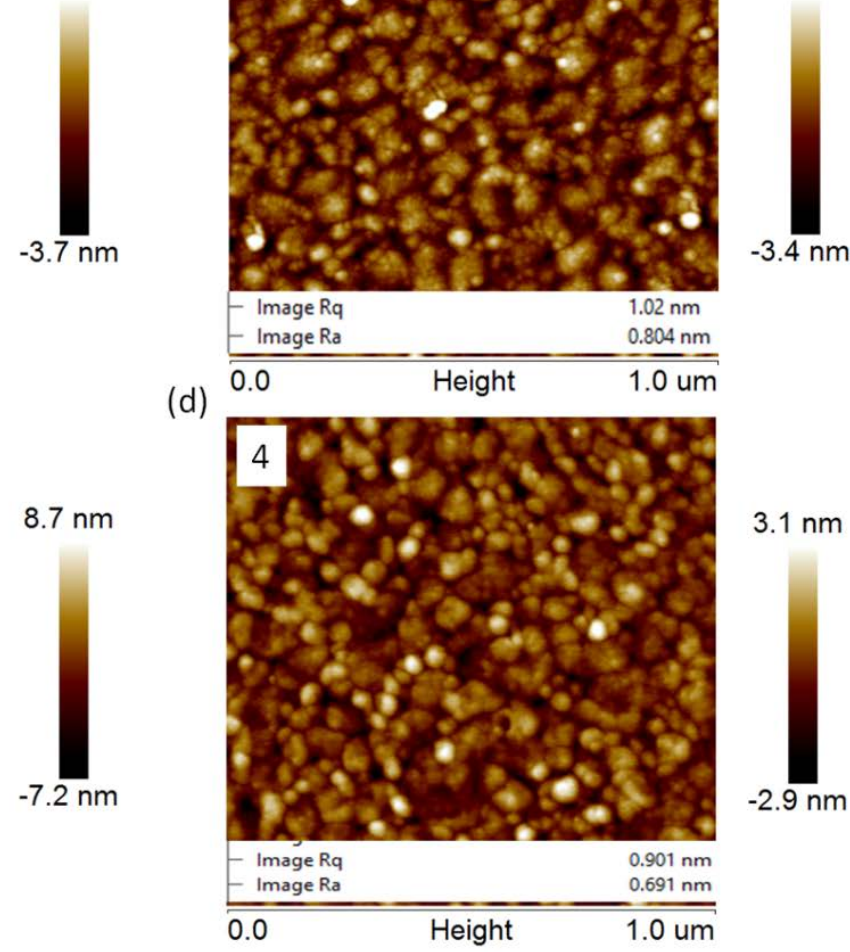

$3.1 \mathrm{~nm}$

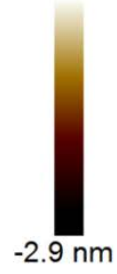

Figure S7. Morphologies of peptide monolayers on Au surface measured by AFM. (a) peptide 1; (b) peptide 2; (c) peptide 3; (d) peptide 4. 
Table S5. Thickness of peptide monolayers measured by ellipsometry.

\begin{tabular}{lcccc}
\hline & peptide $\mathbf{1}$ & peptide $\mathbf{2}$ & peptide $\mathbf{3}$ & peptide $\mathbf{4}$ \\
\hline Thickness $(\AA)$ & $16.8 \pm 0.8$ & $17.4 \pm 0.79$ & $18.8 \pm 0.07$ & $18.0 \pm 0.29$ \\
\hline
\end{tabular}




\section{Temperature-dependent conductance measurements for peptides}

\section{$\underline{1-4}$}

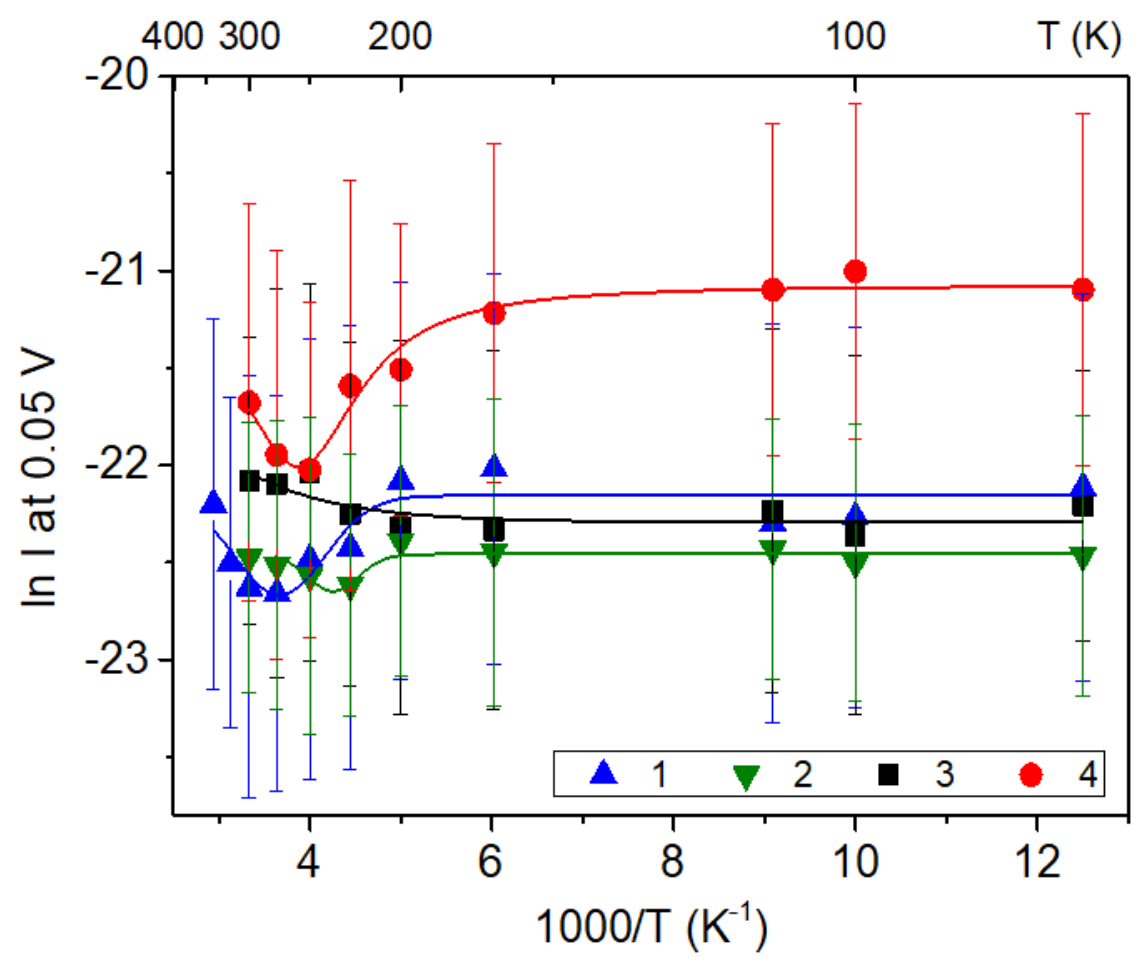

Figure S8. Measured current for peptides 1-4 as a function of temperature ranging between $80 \mathrm{~K}$ and $340 \mathrm{~K}$. Error bars indicate the deviations of measured current over 20 junction devices. 
6. Temperature-dependent $\alpha$-helical content of self-assembled peptides 1-4

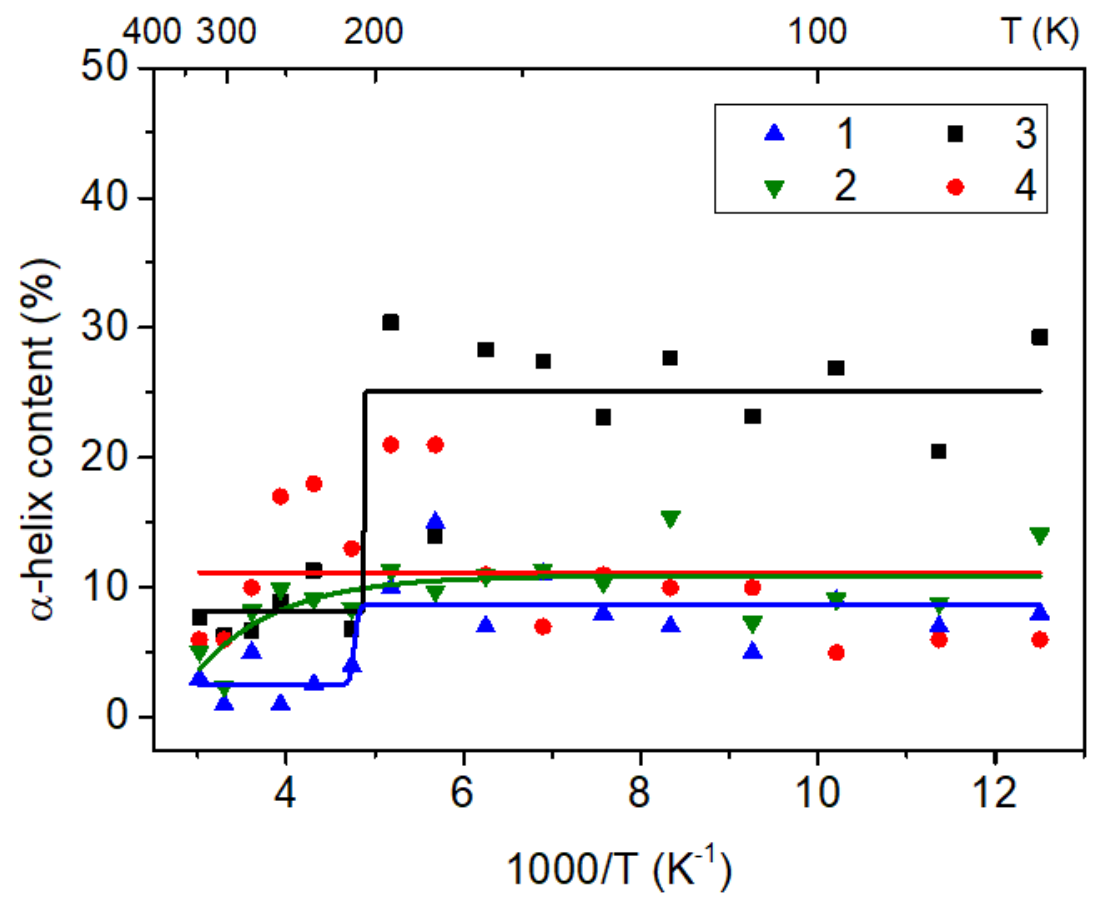

Figure S9. Temperature-dependent $\alpha$-helical content of self-assembled peptides 1-4. 


\section{Analysis of MD data for mobility (RMSF) per residue}
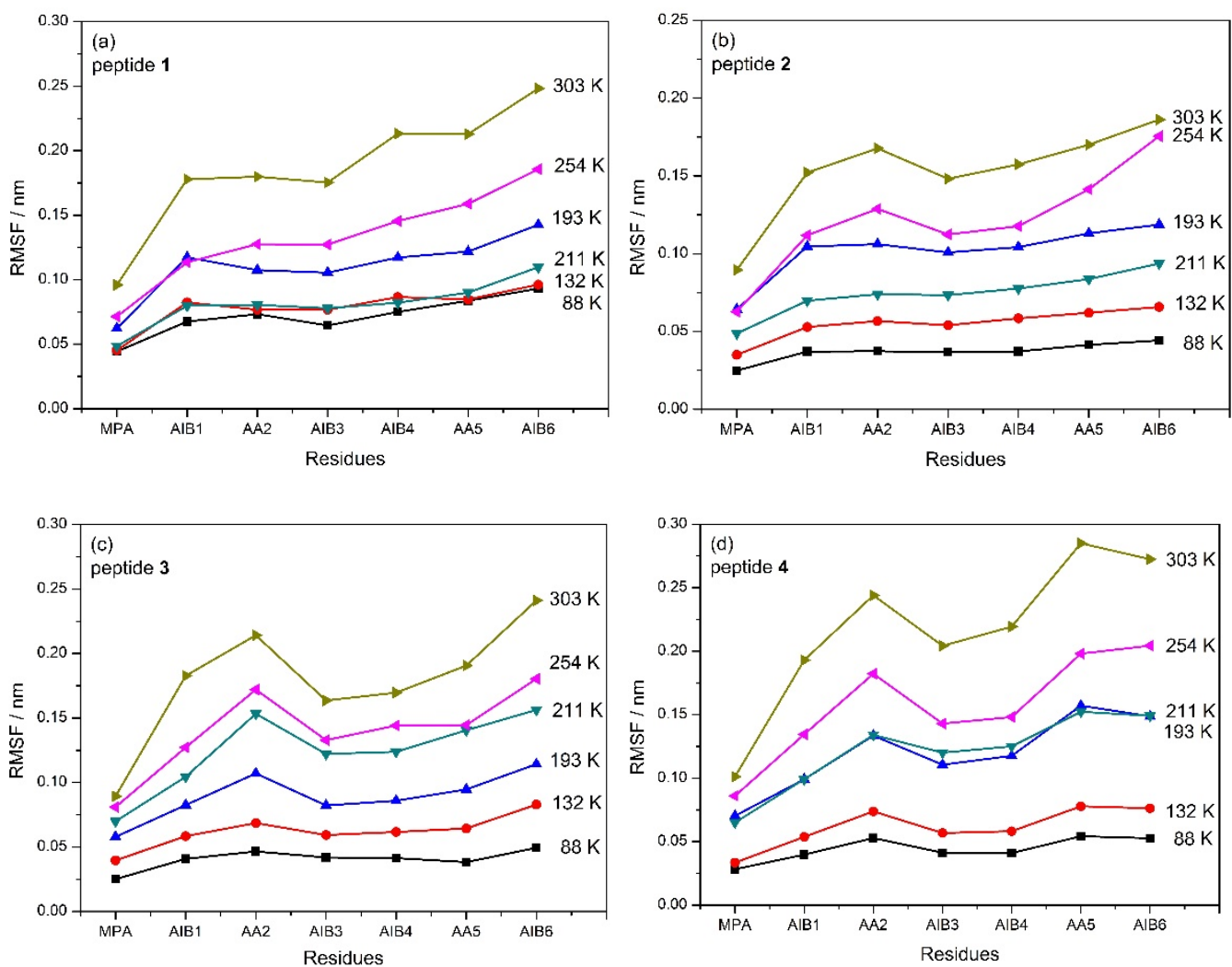

Figure S10. The mobility (RMSF, root mean square fluctuations) per residue around the average position in monolayers containing each of the four peptides at different temperatures.

Figure S10 depicts the mobility of each residue in the peptides around their average positions in the monolayers at different temperatures. At a given temperature, the MPA linker has the lowest RMSF value as it binds to the surface via an Au-S bond, while the residues nearest to the distant C-terminal generally have higher RMSF values. For peptides $\mathbf{1}$ and $\mathbf{2}$ which are constrained into a macrocycle by a side bridge, the RMSF value per residue gradually increases with elevating temperature from $88 \mathrm{~K}$ to $193 \mathrm{~K}$. However, after increasing to $211 \mathrm{~K}$, a sudden drop in the RMSF values is observed for the two peptides. With the temperature further increasing from $211 \mathrm{~K}$ to $303 \mathrm{~K}$, the RMSF values per residue rise again. It is worth noting that the four residues within the macrocycle loop of peptides $\mathbf{1}$ and $\mathbf{2}$, namely the two tethered AA2, AA5, and AIB3, AIB4, each have relatively similar RSMF values for any given temperature, compared to linear peptides $\mathbf{3}$ and $\mathbf{4}$. The collective motions of the 
macrocycle induce an accumulated potential energy (dihedral / angle strain) in the loop. This energy build-up is released at approximately $211 \mathrm{~K}$, with the result being a lower 3 -helical content in the peptides. For the linear peptide 3 with an alanine at AA5, the RMSF value per residue rises with increasing temperature, from $211 \mathrm{~K}$ to $303 \mathrm{~K}$, with no sudden drop of RMSF values. Peptide $\mathbf{4}$ with its modified alkene at AA5, has a higher RMSF value per residue than that of $\mathbf{3}$ throughout the entire sequence, with the modified alkene always having the highest RMSF value in the sequence at any given temperature. This is because the alkene-containing side chain is much longer and more flexible than the alanine one in $\mathbf{3}$, and is positioned much further from the surface. This helps explain why the $3_{10}$-helical content within peptide 4 is gradually reduced as temperatures increase. 